\title{
The obsolescence of formocresol
}

- Informs the reader of the current medicaments for endodontic procedures, including paediatric pulpotomy and pulp capping.

- Updates the warnings and contra-indications for the use of formaldehyde in dentistry.

- Allows the reader to re-evaluate and choose from several newer and less toxic and genotoxic medicaments than formocresol for any type of endodontic procedure.

Concern has existed for almost ten years regarding the safety and efficacy of formaldehyde-based medicaments like formocresol in dentistry. Formocresol has been shown to be therapeutically outdated for decades. While the use of formocresol around the world continues to drop, it is still utilised in alarmingly high rates, an age-old bias that is unsubstantiated by overall academic research. Formaldehyde remains a genotoxic and carcinogenic problem worldwide. The most recent articles are discussed in the light of the need to abandon formocresol.

This paper is intended to provide a current review of the literature, which generally reinforces the notion that formocresol is an archaic medicament and its associated applications deleterious, causing worldwide concern and a call for its elimination. ${ }^{1}$ Yet, defence of formocresol use continues. ${ }^{2}$

In 1981, this author published the original compendium of research dealing specifically with the use of the carcinogens formaldehyde, cresol and paraformaldehyde in endodontic procedures; aimed at all general practice clinicians and specialists. ${ }^{3-5}$ The original two-year project started a debate that continues: why haven't we eliminated formaldehyde-containing medicaments like formocresol from the dental armamentarium? The addition of cresol to the compound had only increased the deleterious effects.

Paraformaldehyde paste was also found unacceptable, both as a medicament and part of an endodontic procedure that did not utilise a full pulpectomy. An updated version of the 1981 article, published in 1998, reviewed separately the 1980s and

\footnotetext{
'Former Program Coordinator in Postdoctoral Endodontics at St Luke's-Roosevelt Hospital and Columbia University, New York City and former Attending at Cedars-Sinai Medical Center, Los Angeles Correspondence to: Dr Bradley Lewis, 934 n. Foothill Road, Beverly Hills, 90210, United States Email: bbllewis@sbcglobal.net
}

\section{Refereed Paper}

Accepted 8 October 2009

DOI: $10.1038 /$ sj.bdj.2009.1103

${ }^{\oplus}$ British Dental Journal; 207: 525-528 1990s research for carcinogenicity and the then-recent research on formocresol, adding 71 references to original $115 .^{6}$ Several letter exchanges have occurred in journals since $1981 .^{7,8}$ The most recent ones were published in several journals. ${ }^{9-13}$

\section{Formocresol today}

Despite the hundreds of articles that have supported the mutagenicity (genotoxicity), carcinogenicity and toxicity of formaldehyde, formocresol is still used today in full strength by an alarming number of clinicians around the world. ${ }^{14}$ Formocresol is widely accepted for vital pulpotomy. The simple definition of vital pulpotomy involves the surgical amputation of the coronal portion of exposed vital pulp and the placement of a dressing over the exposed, healthy pulp stumps.

Despite the overwhelming body of research, some specialty groups still consider formaldehyde as a suitable dressing. Ninety-two board-certified paediatric dentists recently responded to a questionnaire. Of them, the vast majority, some $73 \%$, still used formocresol; 28\% were still using a full strength formulation. The group ignored the adverse effects of formaldehyde-based medicaments. ${ }^{15}$

At the beginning of 2008, Dunston and Coll repeated a 1997 survey that questioned the undergraduate paediatric dentistry chairs and board certified paedodontists who had been surveyed in 2005. Diluted formocresol was still used frequently, but was now down to 54\%, with an increased usage of ferric sulphate and calcium hydroxide as alternative medicaments.

Clinicians should be advised that using formocresol is not recommended by the American Association of Endodontists and the American Academy of Pediatric Dentistry. Some programme directors and diplomats ignore the majority recommendations and understanding of their own specialty organisation. ${ }^{16}$ Seal and Glickman have reported on the November 2007 pulp therapy symposium of those two organisations. One of the clear understandings held between those pulp therapy specialty groups, a result of chi-2 tests given before and after the symposium, is that formocresol should not be a primary tooth pulpotomy agent. Mineral trioxide is the acceptable replacement. ${ }^{17}$

Ironically, formocresol pulpotomy is still the most frequently used procedure for asymptomatic caries that endangers the pulp chamber in primary teeth. Indirect pulp therapy, IPT, has been show to be an effective alternative to the full pulpotomy. Still, within the United States, full formocresol pulpotomy remains the most popular, even though it may be obsolete and should not be the first choice instead of IPT. ${ }^{18}$

Dosage is also a problem. Years ago, the manufacturers of Buckley's formocresol explained to this author that the percentages listed on the packaging were an estimate and variations sold around the world could differ in their formaldehyde 
component by more than 10\%. Some authors have wrongly equated mg with ppm: $1 \mathrm{mg} /$ litre is $1 \mathrm{ppm}$. Using the archaic method of squeezing a No. 4 pellet, the resulting dose estimates reported (utilising a 1:5 dilution of formocresol) a range from 0.02 to $1 \mathrm{mg}$ per dose.

Authors who defend the use of formocresol admit that the dose is clearly unknown and it remains an important area for future research. ${ }^{19}$ Proponents of this type of methodology have never utilised reliable and reproducible studies, advantaged by a simple mean and standard deviation..$^{20}$

Much of the literature for the continuance of formocresol is supported by pharmaceutical chemists and argues that since formaldehyde is so prevalent in our daily lives, it matters little if we introduce a small uncalculated dose into the systems of children. For some authors, formaldehyde released into the system poses little concern when juxtaposed against the undesirable amounts already in the food and environment. ${ }^{21}$

Milnes, in a minority perspective, has written that since antibiotics are used frequently and cause death, why should we be concerned about formaldehyde? ${ }^{19}$ As clinicians we should be trying to reduce the amounts of potentially harmful medicaments delivered to our patients, particularly when so many alternatives exist.

\section{Genotoxicity and carcinogenicity}

There is overwhelming worldwide concern about the risk of environmental mutagens and carcinogens like formaldehyde to children. ${ }^{22}$ For decades, increases in cancer have been linked to mutagenic and carcinogenic agents. Since June 2004, the International Agency for Research on Cancer has reclassified formaldehyde as a known human carcinogen. ${ }^{23}$ Recently, formaldehyde was strongly associated with leukaemia while generally accepted as a direct cause of nasopharyngeal cancer. ${ }^{24}$

Despite any clinical success in its usage, it is currently accepted that attention must be paid to the mutagenic (genotoxic) and carcinogenic properties of medicaments. In early 2008, Ribeiro reviewed the need to consider genotoxicity in the hope of improving our approach to general oral health while being certain that we are not contributing to oral carcinoma. ${ }^{25}$ Formaldehyde medicaments are capable of causing noxious activity on the actual genetic makeup of a cell. Strangely, much of Ribeiro's work with in vitro single cell gel (comet) assay indicates little if any genetic damage by formocresol, and he is quoted in recent articles. ${ }^{26-28}$ However, Hagiwara, using Syrian hamster embryo (SHE) cells, found that the percentages of cells with chromosomal aberrations, polyploidy or endoreduplication were increased by formocresol.

The dosage in the Hagiwara study was 14,090 times less strength than the standard used in clinical pulpotomy treatment on children. ${ }^{29}$ Nishimura et al. demonstrated genotoxic events using 0.001 percent formalin - the dose of formaldehyde in Buckley's formocresol is 19,000 times greater. ${ }^{30}$ Formaldehyde and m-cresol still show genotoxic effects to mammalian cells in other studies using SHE. ${ }^{31}$ It is clear this area needs further study.

Liver toxicity associated with formocresol shows mixed results, depending upon the animal studies. Some rat studies have shown little if any effect on the liver. ${ }^{32}$ In 2000, Hamaguchi showed the genotoxicity of seven dental antiseptics, among them $\mathrm{m}$-cresol and formaldehyde. Again utilising SHE, Hamaguchi concluded that both medicaments were genotoxic to mammalian cells. ${ }^{33}$ Formaldehyde is a genotoxic substance. Studies show that formaldehyde induces DNA-protein crosslinking causing DNA lesions. Recent studies have shown that formaldehyde induces mutations in mouse lymphoma assay. Mutant colonies are created, likely by inducing chromosomal aberrations. ${ }^{34}$

Using human buccal cells, Lu et al. demonstrated DNA breaking and crosslinking activity. He concluded that the results of gaseous formaldehyde with the comet test indicated that formaldehyde increased the possibility of cancer at high levels. ${ }^{35}$ The difficulty in interpreting the individual genotoxic effect of a single pulpotomy is obviously very difficult and cannot be done in vivo. Looking at the peripheral blood cells of a single child who has had a formocresol pulpotomy is interesting, but work with statistical significance would mean long-term human studies. ${ }^{36}$ Outside of dentistry, the US Occupational Safety and Health Administration (OSHA) has been making every effort to see that formaldehyde is monitored properly. ${ }^{37}$

The more detailed arguments at the cellular and DNA/chromosomal level are beyond the scope of this article. Multitudes of supportive research exist to make arguments based on extrapolation of data to nonrelated clinical fields, sometimes a faulty link, particularly when like dosage and exposure data are unavailable in paediatric dentistry and endodontics. Discussion of cancer research methodologies and assays in individual medical research specialty articles should be left to other literature and international cancer experts; and perhaps should no longer be dissected in reviews by dental clinicians.

\section{Current pulpotomy medicaments}

For many years, clinicians have substituted a variety of medicaments for formocresol. The potpourri of historic nineteenth and early twentieth century concoctions have often proved as effective as formocresol. Today, modern cements and chemical mixtures have been added. The use of older medicaments like zinc oxide is still being tested, with generally favourable outcomes. ${ }^{38}$ Caceda has developed a contemporary technique that utilises a resin-based composite filling material: fast-setting ZOE Temrex cement, a zinc oxide, and eugenol (oil of cloves) product, but still performs the formocresol pulpotomy. ${ }^{39}$ This article illustrates the reluctance of clinicians to omit formocresol, even from newer procedures that may not require it, in this case because of the presence of ZOE.

Vargas and others haves shown success with sodium hypochlorite as a pulpotomy medicament. ${ }^{40,41}$ Even a 'green' approach exists, utilising the nineteenth century essential oil cinnamaldehyde, from cinnamon, with promising results in rat pulp capping when compared to formocresol. ${ }^{42}$

Generally, the popular medicaments are ferric sulphate (FS), calcium hydroxide (CH) and mineral trioxide aggregate (MTA). ${ }^{43}$ In 2008, a clinical study by Sonmez et al. found nearly equal success rates for FS as for formocresol. ${ }^{44}$ While slightly lower success rates were shown for MTA and $\mathrm{CH}$, this paper, like so many around the world, makes any well-meaning clinician take pause and wonder why formocresol is still the yardstick so many years after it was discredited. Sophisticated research, 


\section{Table 1 Medicaments at a glance}

\begin{tabular}{l|l|l|l}
\hline Medicaments & Cytotoxic & Genotoxic & Carcinogenic \\
\hline Formocresol & Yes & Yes & Yes \\
\hline ZOE & Low & Low & $?$ \\
\hline MTA & No & No & No \\
\hline FS & Yes & Low & No \\
\hline CH(CAOH) & Low & No & $?$
\end{tabular}

like that of $\mathrm{Ng}$ and Messer, established composite statistical meta analysis results from a broad range of pulpotomy articles that were concerned with the efficacy of MTA, formocresol, FS, and CH.

Using the established standards of clinical and radiograph success, MTA outshone formocresol, FS, and $\mathrm{CH}^{45}$ Moretti et al. found similar results in a controlled study that had up to 24 month follow-ups. $\mathrm{CH}$ showed a higher incidence of internal root resorption. ${ }^{46}$ A light-cured version of $\mathrm{CH}$ did not fare as well as other studies and conditions. ${ }^{47}$ Many studies have shown positive results for MTA when compared with formocresol. ${ }^{48}$ Upon histological examination animal studies have shown superior results for MTA, white Portland cement (WPC), and beta-tricalcium phosphate (b-TCP) over formocresol and FS. ${ }^{49}$ Other promising possibilities include enamel matrix derivative (EMD), a material that utilises active odontogenic protein. ${ }^{50}$

The majority of research at the present time points to MTA as the most popular choice because of its predictability in preserving pulpal health while promoting healing and regeneration of pulp tissue. Generally, MTA offers far better outcomes than formocresol, which contributes to post-treatment disease (Table 1). ${ }^{51-54}$

Recently, Bahrololoomi et al. examined the success rates of electrosurgery as opposed to formocresol pulpotomy. The failure rate in booth groups did not show any statistical significance on the 70 primary molars of 5- to 10 -year-olds; evidence that alternatives to medicaments should be examined and studied further. ${ }^{55}$ Lasers are also making headway as a progressive alternative to formocresol. ${ }^{56,57}$

\section{Conclusion}

Revival of age-old remedies are often advantageous as well-known, effective, innocuous, and sometimes scientific adjunct for a variety of ailments. ${ }^{58}$ The same cannot be said of long-standing formocresol due to its harmful effects and lack of scientific support.

Formocresol is very likely no longer suitable for use in dentistry, with emphasis on its applications in children's dentistry. In 2006, Fuks aptly concluded after examining a review of the pulpotomy literature from 1966-2005, 'More high quality, properly planned prospective studies are necessary...' although noted that MTA is currently the most favourable choice. ${ }^{59}$ As many others before, Fuks reported in 2008 that suitable alternatives to formocresol exist. ${ }^{60}$ old-fashioned formaldehyde products like formocresol as problematic because of its toxicity, carcinogenicity, and genotoxicity. There are several viable and superior noninvasive clinical alternatives. Formocresol should be abandoned.

1. Casas M J, Kenny D J et al. Do we still need formocresol in pediatric dentistry? J Can Dent Assoc 2005; 71: 749-751.

2. Milnes A R. Is formocresol obsolete? A fresh look at the evidence concerning safety issues. J Endod 2008; 34 suppl: S40-S46.

3. Vaughan C, Stanfill S B et al. Automated determination of seven phenolic compounds in mainstream tobacco smoke. Nicotine Tob Res 2008; 10: 1261-1268.

4. Li Y, Qu M et al. Genotoxicity study of phenol and 0 -cresol using the micronucleus test and the comet assay. Environ Toxico/ Chem 2005; 87: 365-372.

5. Lewis B B. Formaldehyde in dentistry: a review of mutagenic and carcinogenic potential. J Am Dent Assoc 1981; 103: 429-434.

6. Lewis B. Formaldehyde in dentistry: a review for the millennium. J Clin Pediatr Dent 1998; 22: 167-177.

7. Lewis B B. The formaldehyde debate. J Am Dent Assoc 1982; 104: 816, 818.

8. Lewis B B. Formaldehyde in dentistry. J Am Dent Assoc 1993; 124: 14, 16.

9. Lewis B B. Safety of formocresol in dentistry. J Okla Dent Assoc 2008; 99: 8.

10. Lewis B B. Safety of formocresol contested. J Calif Dent Assoc 2008; 36: 323.

11. Lewis B B. Formocresol use unwarranted. NYState Dent J 2008; 74: 10

12. Lewis B B. Safety of formocresol. J Ir Dent Assoc 2008; 54: 108.

13. Lewis B B. Formocresol in dentistry. Br Dent J 2008; 204: 477.

14. Fuks A B. Vital pulp therapy with new materials for primary teeth: new directions and treatment perspectives. Pediatr Dent 2008; 30: 211-219.
The decades of research have identified
15. Yoon R K, Chussid S et al. Preferred treatment methods for primary tooth vital pulpotomies. A survey. N Y State Dent J 2008; 74: 47-49.

16. Dunston $B$, Coll J A. A survey of primary tooth pulp therapy as taught in US dental schools and practiced by diplomates of the American Board Of Pediatric Dentistry. Pediatr Dent 2008; 30: 42-48.

17. Seale N S, Glickman G N. Contemporary perspectives on vital pulp therapy: views from the endodontists and pediatric dentists. Pediatr Dent 2008; 30: 261-267.

18. Coll J A. Indirect pulp capping and primary teeth: is the primary tooth pulpotomy out of date? Pediatr Dent 2008; 30: 230-236.

19. Milnes A R. Is formocresol obsolete? A fresh look at the evidence concerning safety issues. J Endod 2008; 34 suppl: S44.

20. Ruby J D. Personal communication via email. University of Alabama, Birmingham, Department of Pediatric Dentistry. 10 Oct 2008.

21. Dhareshwar S S, Stella V J. Your prodrug releases formaldehyde: should you be concerned? No! J Pharm Sci 2008; 97: 4184-4193.

22. Belpomme $D$, Irigaray $P$ et al. The multitude and diversity of environmental carcinogens. Environ Res 2007; 105: 414-429. Comment in: Environ Res 2008; 107: 288; discussion 289-290.

23. Cogliano V, Grosse Y et al. Meeting report: summary of IARC Monographs on formaldehyde, 2-utoxyethanol, and 1-tert-butoxy-2-propanol. Environ Health Perspect September 2005.

24. Zhang L, Steinmaus $C$ et al. Formaldehyde exposure and leukemia: a new meta-analysis and potential mechanisms. Mutat Res 2009; 681: 150-168.

25. Ribeiro D A. Do endodontic compounds induce genetic damage? A comprehensive review. Oral Surg Oral Med Oral Pathol Oral Radiol Endod 2008; 105: 251-256.

26. Ribeiro D A, Scolastici C. Genotoxicity of antimicrobial endodontic compounds by single cell gel (comet) assay in Chinese hamster ovary (CHO) cells. Oral Surg Oral Med Oral Pathol Oral Radiol Endod 2005; 99: 637-640.

27. Ribeiro D A, Marques M E, Salvadori D M. Lack of genotoxicity of formocresol, paramonochlorophenol, and calcium hydroxide on mammalian cells by comet assay. J Endod 2004; 30: 593-596.

28. Milnes A R. Persuasive evidence that formocresol use in pediatric dentistry is safe. $J$ Can Dent Assoc 2006; 72: 247-248.

29. Hagiwara M, Watanabe $E$ et al. Assessment of genotoxicity of 14 chemical agents used in dental practice: ability to induce chromosome aberrations in Syrian hamster embryo cells. Mutat Res 2006; 603: $111-120$.

30. Nishimura $H_{1}$ Higo $Y$ et al. Ability of root canal antiseptics used in dental practice to induce chromosome aberrations in human dental pulp cells. Mutat Res 2008; 649: 45-53.

31. Hikiba $H$, Watanabe $E$ et al. Ability of 14 chemical agents used in dental practice to induce chromosome aberrations in Syrian hamster embryo cells. J Pharmacol Sci 2005; 97: 146-152.

32. Cortés 0 , Fernández $J$ et al. Effect of formaldehyde on rat liver in doses used in pulpotomies. J Clin Pediatr Dent 2007; 31: 179-182.

33. Hamaguchi F, Tsutsui T. Assessment of genotoxicity of dental antiseptics: ability of phenol, guaiacol, p-phenolsulphonic acid, sodium hypochlorite, $\mathrm{p}$-chlorophenol, m-cresol or formaldehyde to induce unscheduled DNA synthesis in cultured syrian hamster embryo cells. Jpn J Pharmacol 2000; 83: 273-276.

34. Speit G, Merk O. Evaluation of mutagenic effects of formaldehyde in vitro: detection of crosslinks and mutations in mouse lymphoma cells. Mutagenesis 2002; 17: 183-187.

35. Lu Z-S, Yan Y et al. Studies on genotoxicity of gaseous formaldehyde on human buccal cells. China Environ Sci 2003; 23: 566-569.

36. Zarzar P A, Rosenblatt A et al. Formocresol mutagenicity following primary tooth pulp therapy: an in vivo study. J Dent 2003; 31: 479. 
37. Lavoue J, Vincent R, Gerin M. Formaldehyde exposure in US industries from OSHA air sampling data. J Occup Environ Hyg 2008; 5: 575-587.

38. Chédid J C, Pilipili C. A 24-month evaluation of zinc oxide pulpotomy on primary canines. Rev Belge Med Dent 2008; 63: 69-76.

39. Caceda J H. The use of resin-based composite restorations in pulpotomized primary molars. J Dent Child (Chic) 2007; 74: 147-150.

40. Vargas K G, Kaaren B, Lowman D. Preliminary evaluation of sodium hypochlorite for pulptomies in primary molars. Pediatr Dent 2006; 28: 511-517.

41. Calderon $L$ et al Abstract of presentation at the 2007 American Academy of Pediatric Dentistry, San Antonio, Texas.

42. Gao H Y, Li W Y et al. Histopathology research of cinnamaldehyde as pulp-cap of pulpotomy in rats. Hua Xi Kou Qiang Yi Xue Za Zhi 2007; 25: 429-431.

43. Peng $L$, Ye $L$ et al. Evaluation of formocresol versus ferric sulphate primary molar pulpotomy: a systematic review and meta-analysis. Int Endod J 2007; 40: 751-757.

44. Sonmez D, Sari S, Cetinbaş T A. Comparison of four pulpotomy techniques in primary molars: a long-term follow-up. J Endod 2008; 34: 950-955.

45. Ng F K, Messer L B, Mineral trioxide aggregate as a pulpotomy medicament: an evidence-based assessment. Eur Arch Paediatr Dent 2008; 9: 58-73.

46. Moretti A B, Sakai V T et al. The effectiveness of mineral trioxide aggregate, calcium hydroxide and formocresol for pulpotomies in primary teeth. Int Endod J 2008; 41: 547-555.

47. Zurn D, Seale N S. Light-cured calcium hydroxide versus formocresol in human primary molar pulpotomies: a randomized controlled trial. Pediatr Dent 2008; 30: 34-41.

48. Noorollahian H. Comparison of mineral trioxide aggregate and formocresol as pulp medicaments for pulpotomies in primary molars. Br Dent J 2008; 204: E20.

49. Shayegan A, Petein M, Abbeele A V. Beta-tricalcium phosphate, white mineral trioxide aggregate, white Portland cement, ferric sulphate, and formocresol used as pulpotomy agents in primary pig teeth. Oral Surg Oral Med Oral Pathol Oral Radiol Endod 2008; 105: 536-542.

50. Sabbarini J, Mohamed A et al. Comparison of enamel matrix derivative versus formocresol as pulpotomy agents in the primary dentition. J Endod 2008; 34: 284-287.

51. Ng F K, Messer L B. Mineral trioxide aggregate as a pulpotomy medicament: a narrative review. Eur Arch Paediatr Dent 2008; 9: 4-11.

52. Haney K L. Current trends in primary tooth pulp therapy. J Okla Dent Assoc 2007; 99: 28-37, quiz 38.

53. Innes N. Better outcomes in pulpotomies on primary molars with MTA. Comment on: Oral Surg Oral Med Oral Pathol Oral Radiol Endod 2006; 102: e40-e44. Evid Based Dent 2007; 8: 11-12.
54. Aeinehchi M, Dadvand S et al. Randomized controlled trial of mineral trioxide aggregate and formocresol for pulpotomy in primary molar teeth. Evid Based Dent 2007; 8: 107.

55. Bahrololoomi Z, Moeintaghavi A et al. Clinical and radiographic comparison of primary molars after formocresol and electrosurgical pulpotomy: a randomized clinical trial. Indian J Dent Res 2008; 19: 219-223.

56. Toomarian L, Fekrazad R et al. Histopathological evaluation of pulpotomy with Er, Cr: YSGG laser versus formocresol. Lasers Med Sci 2008; 23: 443-450.

57. Odabaş M E, Bodur $\mathrm{H}$ et al. Clinical, radiographic, and histopathologic evaluation of $\mathrm{Nd}$ : YAG laser pulpotomy on human primary teeth. J Endod 2007; 33: 415-421.

58. Rennard B O, Ertl R F et al. Chicken soup inhibits neutrophil chemotaxis in vitro. Chest 2000; 118: 1150-1157.

59. Fuks A B, Papagiannoulis L. Pulpotomy in primary teeth: review of the literature according to standardized criteria. Eur Arch Paediatr Dent 2006; 7: 64-71, discussion 72. Comment in Eur Arch Paediatr Dent 2006; 7: 124.

60. Fuks A B. Vital pulp therapy with new materials for primary teeth: new directions and treatment perspectives. J Endod 2008; 34 Suppl: S18-S24 